\title{
JOLANTA VASKELIENE
}

Šiauliu universitetas

DE்L DARINIŲ SU BAIGMENIU -EIVIS, $-\dot{E}$

ESMINIAI ŽODŽIAI: darybos būdas; darybos kategorija; darybos tipas; baigmuo; priesaga; sinonimiškumas.

\section{ANOTACIJA}

Lietuvių kalboje yra asmenis pavadinančių darinių, turinčių panašius baigmenis -eiva ir -eivis, - $\dot{e}$. Žodžiu darybos veikaluose rašoma apie priesagos -eiva darybos tipą, o apie -eivis, $-\dot{e}$ darinius tik vienur kitur užsimenama. Šiame straipsnyje taikant darybinès, semantinès analizès ir substitucijos metodus analizuojami Lietuvių kalbos žodyne, Dabartinès lietuvių kalbos žodyne, Bendrinès lietuvių kalbos žodyno antraštyne, Skaitmeninès Lietuvių kalbos žodyno papildymu kartotekoje, Lietuvių kalbos naujažodžiu duomenyne ir Dabartinès lietuviu kalbos tekstyne rasti dariniai, turintys baigmeni -eivis, $\dot{e}$. Mokslinès literatūros ir empirinès medžiagos analizė atskleidè, kad dalis baigmeni -eivis, - $\dot{e}$ turinčių darinių yra mišrios darybos (kompozicijossufiksacijos rezultatas), bet tam tikrais atvejais (sinchroniškai) -eivis, $-\dot{e}$ galima laikyti priesaga. Taigi žodžiu darybos veikaluose vardažodinès ypatybės turètojų, veikejju ir veiksmažodinès ypatybès turètoju darybos kategorijose greta esamo -eiva darybos tipo būtų tikslinga nurodyti ir besiformuojantic -eivis, $-\dot{e}$ darybos tipą.

IVADAS

Lietuvių kalboje yra keturi pagrindiniai žodžių darybos būdai: sufiksacija, duodanti priesagų vedinių, prefiksacija, duodanti priešdèlių vedinių, paradigm(iz)acija, duodanti galūnių vedinių, ir kompozicija, duodanti dūrinių. Kartais išsyk reiškiasi du darybos būdai - paprastai prefiksacija ir sufiksacija, kompozicija ir sufiksacija, taigi kalbama ir apie mišrųij darybos būdą (Urbutis 2009: 107, 333-342; dar žr. LKG 1965: 591; Keinys 1999: 22-23)1. Pasakytina, kad lietuvių kalboje yra atvejų, kai dẻl konkrečių darinių darybos būdo nėra vienos nuomonès.

\footnotetext{
${ }^{1}$ Straipsnyje remiamasi žodžių daryba, aprašyta Lietuvių kalbos gramatikoje (LKG 1965: 1971), Dabartinès lietuviu kalbos gramatikoje (DLKG 2005), Vinco Urbučio Žodžiu darybos teorijoje (2009), Stasio Keinio Bendrines lietuvių kalbos žodžių daryboje (1999). Naujas įžvalgas apie darybos būdus žr. Smetona 2005. Už vertingas pastabas ir patarimus dèkoju slaptiesiems(-osioms) recenzentams(-èms).
} 
Pavyzdžiui, skaitvardžius nuo vienuolika iki devyniolika vieni laiko dūriniais, „kurių antrasis sandas remiasi veiksmažodžiu liko“ (Keinys 1999: 84; plg. LKG 1965: 619-620, 636), Aldona Paulauskienė (1994: 237) juos vadina sąaugomis su antruoju dèmeniu -lika, „kuris kilmès požiūriu siejamas su daiktavardžiu liekas - „tai, kas lieka, nereikalinga“. Antano Pakerio Akcentologijos antrojoje dalyje (Pakerys 2002: 22) tokie skaitvardžiai aptariami prie dūrinių, bet rašoma, kad „,[D]abartinejje kalboje antrasis dėmuo jau sunkiai besusiejamas su veiksmažodžiu likti, liko, todèl galima manyti, kad -lika įgyja sufiksoido funkcijas“‘2.

Lietuvių kalboje daiktavardžiai daromi visais žodžių darybos būdais, ypač daug jų padaryta (ir daroma) su priesagomis (Ambrazas 1993, 2000; Keinys 1999: 36; DLKG 2005: 86)³. Pagal darybinę reikšmę ${ }^{4}$ priesagų ir galūnių vediniai tradiciškai skirstomi ì darybos kategorijas (darybos klases) - dažniausiai minima 13 daiktavardžių darybos kategorijų (LKG 1965: 253-423; DLKG 2005: 87-145; Urbutis 2009: 330), Stasys Keinys (1999: 37-39) ju išskiria $12^{5}$. Kiekvienai darybos kategorijai priklauso tam tikras darybos tipu ${ }^{6}$ skaičius. Toje pačioje darybos kategorijoje neretai būna skirtingų darybos tipų darinių, kurie (formaliai) turi tokią pat priesagą, bet skirtingas galūnes ${ }^{7}$. Gana dažnai iš to paties pamatinio žodžio sudaryti skirtingiems darybos tipams priklausantys dariniai yra darybiniai sinonimai ${ }^{8}$ - jie turi tokią pat darybinę reikšmę, tapačią arba panašią leksinę reikšmę; tokie bendrašakniai dariniai žodynuose neretai ir aiškinami vienas kitu. Pavyzdžiui, tik galūnėmis skiriasi vardažodinės ypatybès

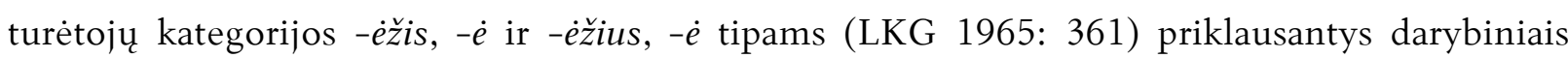
sinonimais laikytini vediniai, pvz., juodėžis, $-\dot{e}$ („,kas negražiai juodas, negražus; juočkis“ LKŽ $\check{e}_{\text {) }}$ ir juodė̌̌ius, $-\dot{e}$ (,,̌̌r. juoděžis“ LKŽ $)$, taip pat $-l y s,-\dot{e}$ ir $-l a^{9}$ tipų dariniai, pvz.: dvoklys, $-\dot{e}$ (,žr.

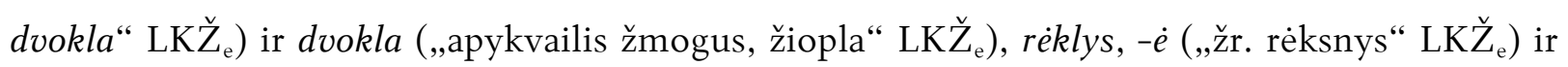

\footnotetext{
${ }^{2}$ Sufiksoidu vadinamas „,[A]ntrasis dūrinio sandas, turintis priesagos bruožų, visų pirma igijięs bendresnę, atsijusią nuo pamatinio žodžio reikšmę“ (Keinys 1999: 114; dar žr. Gaivenis, Keinys 1990: 197).

3 Šiek tiek kitoki nei atraminiuose kalbotyros veikaluose daiktavardžių darybos būdų supratimą pateikia A. Paulauskienè (1994: 64-97).

${ }^{4}$ Straipsnyje vartojamas terminas darybine reikšme (apie darybos reikšmè ir darybinè reikšmè daugiau žr. Kniūkšta 1998).

${ }^{5}$ S. Keinys (1999: 46-47) tos pačios darybos klasės dariniais laiko vardažodinès ypatybės turètojų ir profesinius asmenų pavadinimus.

${ }^{6}$, „Žodžių darybos tipą galima suprasti dvejopai - arba kaip kalboje esančią abstrakčią struktūrinę schemą, pagal kurią sudaromi vis tos pačios (ar kiek varijuojančios) darybos reikšmès ir formos dariniai, arba kaip kalbẻjime esančius pačius tokius darinius, jų visumą“ (Urbutis 2009: 290; plg. Keinys 1999: 24-27).

${ }^{7}$ Kadangi galūnėmis realizuojamos įvairios gramatinės reikšmės, skirtingų galūnių daiktavardžiai dažnai turi ir skirtingų gramatinių reikšmių.

${ }^{8}$ Primintina, kad darybiniai sinonimai yra tapačios arba artimos reikšmès skirtingus darybos formantus turintys bendrašakniai dariniai, o darybiniai variantai - tą pati pamatini žodi (pamatinius žodžius) turintys su tuo pačiu darybos formantu sudaryti dariniai, kurie skiriasi kokiomis nors šalutinėmis darybos priemonėmis: šaknies balsiu ar priebalsiu, jungiamuoju balsiu, priešdėlio variantu ir kt. (daugiau žr. Vaskelienè 2013).

${ }^{9}$ İvairias priesagas (-la, -èla, -ša ir kt.) ir galūnę - $a$ turintys dariniai yra vadinamosios bendrosios giminės (substantiva communia) daiktavardžiai (apie juos žr. Gudzinevičiūtè 2008), o ju sinonimai su kitokiomis galūnėmis (-lys, $-\dot{e},-\dot{e} l i s,-\dot{e},-s ̌ i s,-\dot{e},-s ̌ a s,-a$ ir kt.) turi vyriškąią ir moteriškąą gimines.
} 


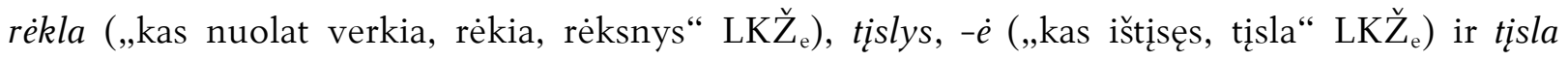
(,ištįsèlis, ilgšis“ LKŽ ${ }_{\mathrm{e}}$ ), vejplys, $-\dot{e}$ (,,vejpla, žioplys“ LKŽ $\check{\mathrm{e}}_{\text {) }}$ ir vépla (,menkos nuovokos žmogus, išsiblaškèlis, išsižiojèlis, žioplys“ $L K Z_{\mathrm{e}}$ ). Veikejjų ir veiksmažodinès ypatybès turètojų darybos kategorijoje galūnèmis skiriasi vienos dariausių priesagos $-\dot{e} l i s,-\dot{e}$ ir menko darumo priesagos - èla tipų (žr. LKG 1965: 318-319, 335) tokią pat arba labai panašią reikšmę turintys, taigi DS laikytini dariniai nemokèlis, $-\dot{e}$ (,„nemokša“ LKŽ $\check{e}_{\mathrm{e}}$ ) ir nemokèla (,žr. nemokša“ LKŽ laikomi $-v i s,-\dot{e}(-v y s,-\dot{e})$ ir $-v a$ tipai, taigi DS eiles sudaro darybiniai variantai ateivis, $-\dot{e} /$ ateivys, $-\dot{e}$ (,atėjęs, atvykęs iš kitur žmogus, atejjūnas“ $\mathrm{LKŽ}_{\mathrm{e}}$ ) ir ateiva (,ateivis“ LKŽ $\check{\mathrm{e}}$ ), pereivis, $-\dot{e}$ (,perèjūnas“ $L K \check{Z}_{\mathrm{e}}$ ) ir pereiva (,perèjūnas“ $L K \check{Z}_{\mathrm{e}}$ ). DS laikytini ir skirtingiems darybos tipams priklausantys galūnėmis besiskiriantys priesagos -š- (-šas, - $\dot{e}$; -šis, - $\dot{e}$; $-\check{s} a)$ vediniai, pvz.: klaikšis, $-\dot{e}$ („,kas paklaikęs, kvailas žmogus, klaika“ LKŽe $)$ ir klaikšas, -e (,,̌̌r. klaikšis“ LKŽ ${ }_{\mathrm{e}}$ ),

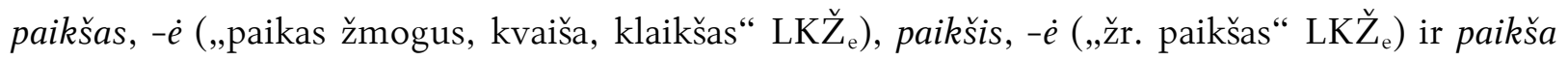
(,„̌rr. paikšas“ $\left.L K \check{Z}_{\mathrm{e}}\right)^{10}$.

Lietuvių kalboje yra asmenis pavadinančių darinių, turinčių panašius baigmenis ${ }^{11}$-eiva ir -eivis, $-\dot{e}$. Priesagos - eiva daiktavardžiais (neretai menkinamai) pavadinami asmenys - kokio nors veiksmo atlikejai arba asmenys, pasižymintys kokia nors ypatybe, pvz.: gudreiva „gudruolis“ LKŽ $\check{e}_{\mathrm{e}}$, karšteiva „karštuolis“ LKŽ rašeiva menk. „prastas rašytojas, grafomanas“ DŽ, kareiva iron. „nevykèlis karys“ LKŽ šventeiva menk. „,kas dedasi šventuoliu, religinis ar moralinis veidmainys“ LKŽ . Daiktavardžiais su -eivis, $-\dot{e}$ taip pat pavadinami vyriškosios arba moteriškosios giminès asmenys, pvz.: darbeivis, - $\dot{e}$ „darbo vykdytojas, rangovas“ LKŽ prižiūri girią“ $L K Z_{\mathrm{e}}$. Žodžių darybos veikaluose rašoma apie priesagos -eiva darybos tipą, o apie -eivis, $-\dot{e}$ darinius tik vienur kitur užsimenama. Taigi, tyrimo objektu ir pasirinkti lietuvių kalbos daiktavardžiai, turintys baigmeni -eivis, $-\dot{e}$. Siekiant straipsnio tikslo - išanalizuoti baigmeni -eivis, $-\dot{e}$ turinčius darinius - keliami tokie uždaviniai: iš mokslinès literatūros surinkti ir pateikti duomenis apie -eiva ir -eivis, -é; iš Lietuvių kalbos žodyno $\left(\mathrm{LKŽ}_{\mathrm{e}}\right)$, Dabartinès lietuviu kalbos žodyno (DŽ), Bendrinès lietuviu kalbos žodyno antraštyno (BŽa), Skaitmeninès „Lietuviu

\footnotetext{
${ }^{10}$ Pasakytina, kad LKG (1965) nèra -šius darybos tipo, o LKŽ paikšis“".

${ }^{11}$ KTŽ nepateiktas terminas baigmuo DŽ aiškinamas kaip „žodžio ar skiemens galas“; ši terminą (greta pradmens) vartoja A. Pakerys - jo Akcentologijoje baigmeniu laikoma formaliai su priesaga sutampanti žodžio (nedarinio) dalis (žr. Pakerys 1994: 6). Straipsnyje kalbama tik apie darinius su -eivis, -é, svarstoma, kokią funkciją daiktavardžių darybos procese atlieka šis baigmuo. Atkreipiamas dèmesys, kad už tyrimo ribų palikti daiktavardžiai, baigmeni -eivis, $-\dot{e}$ gavę iš pamatinių žodžių (paprastai jie yra kitų kalbų pavyzdžiu sudaryti žodžiai) (pvz.: puskareivis (: pusiau, kareivis), draugkareivis (jis laikomas sudėtiniu žodžiu, sudarytu svetimų kalbų pavyzdžiu (žr. Skardžius 1996: 401), taip pat priesagos -vis, $-\dot{e}(-v y s,-\dot{e})$ vediniai (jeivis, $-\dot{e}$, praeivis, $-\dot{e}$ ir kt.), kurių darybos pamatu eina priešdèliniai iš veiksmažodžio eiti išvesti veiksmažodžiai (jeiti, praeiti ir kt.) (apie juos žr. LKG 1965: 331; DLKG 2005: 110-111).
} 
kalbos žodyno“ papildymu kartotekos (LKŽPK) išrinkti baigmeni -eivis, - $\dot{e}$ turinčius darinius, medžiagą papildyti Lietuvių kalbos naujažodžiu duomenyno (ND) ir Dabartinès lietuviu kalbos tekstyno (DLKT) duomenimis, aptarti dariniu su -eivis, - $\dot{e}$ darybą ir semantiką. Tyrimui taikytas darybinès analizès metodas, naudotasi gretinimo, semantinès analizès ir substitucijos metodais.

\section{DARINIAI SU PRIESAGOMIS -EIVA IR -EIVIS, -E KALBOTYROS VEIKALUOSE}

Apie substantiva communia daiktavardžius, turinčius priesagą -eiva, rašoma LKG (1965: 330, 353), DLKG (2005: 110, 119-120), abiejose Sauliaus Ambrazo knygos Daiktavardžiu darybos raida dalyse (1993: 153; 2000: 181), tos priesagos vediniai minimi Prano Skardžiaus Lietuvių kalbos žodžių daryboje (1996: 389), Antano Pakerio Akcentologijoje (1994: 77), Stasio Keinio Bendrinès lietuvių kalbos žodžiu daryboje (1999: 47).

Dèl vedinių, turinčių priesagą -eiva, kalbininkų nuomonės nesiskiria - jie, priklausomai nuo pamatinio žodžio ir darybinès reikšmès, laikomi dviejų darybos kategoriju dariniais ${ }^{12}$ : iš veiksmažodžių išvedami veikèju ir veiksmažodinès ypatybės turètoju pavadinimai, pvz., maineiva (: mainè) ir puošeiva (: puošè), o iš vardažodžiu išvesti dariniai yra vardažodinès ypatybès turètoju pavadinimai, pvz., drūteiva (: drūtas) ir gražeiva (: gražus). Apie vardažodinès kilmès -eiva vedinius DLKG rašoma: „[V]isi šios priesagos vardažodinès ypatybès turètoju pavadinimai - tai asmenis žymintys ir paprastai turintys menkinamosios reikšmès atspalvị bendrosios giminès daiktavardžiai, padaryti iš nesudètingos sandaros kokybinių būdvardžių, pvz.: gražeiva, gudreiva, pikteiva, rimteiva, šventeiva“ (DLKG 2005: 119-120). Veikèju ir veiksmažodinès ypatybės turètojų pavadinimų darybos kategorijos vediniai, turintys priesagą -eiva, yra „padaryti iš veiksmažodžių (paprastai nepriešdẻlinių), žymi asmenis, turi menkinamąją reikšmę ir yra bendrosios giminès, pvz.: mušeiva, puošeiva, rašeiva, skundeiva, verteiva. Iš dalies čia šliejasi ir dariniai kareiva, vadeiva“ (DLKG 2005: 110). S. Ambrazas (1993: 153) taip pat kalba apie dvieju darybos kategoriju -eiva vedinius: veikèjų pavadinimus (išireiva, maineiva, mušeiva, nedereiva) ir ypatybės turètoju pavadinimus (gražeiva, narseiva). Jis pažymi, kad ,[Š]iu vediniu pavyzdžiu bendrineje kalboje padarytas vienas kitas naujadaras, pvz.: pikteiva

\footnotetext{
${ }^{12}$ A. Pakerio Akcentologijoje (1994: 77) priesagos -eiva dariniai (išvesti iš veiksmažodžių ir iš vardažodžių) aptariami kartu - tai suprantama, nes kalbama apie kirčiavimą, o ne apie darinių, formaliai turinčių tokią pat priesagą, skirtybes. Primintina, kad tos pačios darybos kategorijos vediniai vadinami vardažodinès ypatybės turètoju pavadinimais (LKG 1965: 340; Urbutis 2009: 330) arba ypatybės turètojų pavadinimais (Ambrazas 2000). S. Keinys - èla tipo vedinių pavyzdžiu (gudreiva, smarkeiva) pateikia tik kalbėdamas apie vardažodinės ypatybės turètojų ir profesinius asmenų pavadinimus, o aptariant veikejjų ir veiksmažodinės ypatybės turètoju pavadinimus priesaga -èla neminima (Keinys 1999: 47).
} 
„pikčiurna“, rimteiva „kas dedasi rimtas“, šventeiva „šventuolis, veidmainys“ (Ambrazas 2000: 181).

Dèl darinių, turinčių baigmenị -eivis, $-\dot{e}$, vienos nuomonės nèra. P. Skardžiaus Lietuvių kalbos žodžiu daryboje (1996: 436) daiktavardis keleivis, -e pateiktas dūrinių skyriuje, taip pat ir A. Pakerio Akcentologijos pirmojoje dalyje. Tiesa, joje rašoma, kad „dėmuo -eivis, - $\dot{e}$ (su pridètine priesaga -vis, $-\dot{e}$ ), galima sakyti, jau yra virtęs sufiksoidu“ (žr. Pakerys 1994: 288). Moteriškosios giminès daiktavardis plateive toje pačioje knygoje laikomas priesagos -eive vediniu (Pakerys 1994: 87, 288). S. Ambrazas daiktavardi moksleivis (: mokslas) laiko vediniu (1993: 8-9). Manytina, kad galvoje turima priesaga $-e i v i s,-\dot{e}$, bet toks darybas tipas, tokia priesaga knygoje daugiau neminima - darybos afiksų rodyklëje nurodyta tik priesaga -eiva (žr. Ambrazas 1993: 278). Atkreiptinas dèmesys, kad baigmeni -eivis, - $\dot{e}$ priesaga laiko S. Keinys (2005: 63) aptariant terminą oreivis teigiama: ,[N]ors lietuvių kalbos žodžių darybos veikaluose ši priesaga ir nenurodoma, tačiau sinchroniškai ją išskirti galima“ (2005: 63). Kituose minėtuose kalbotyros darbuose - gramatikose, V. Urbučio Žodžiu darybos teorijoje (2009), S. Keinio Bendrinès lietuvių kalbos žodžiu daryboje (1999) - apie darinius su -eivis, - $\dot{e}$ nerašoma.

\section{LIETUVIŲ KALBOS DARINIAI SU BAIGMENIU -EIVIS, $-\dot{E}$}

LKŽ ${ }_{\mathrm{e}}$, LKŽPK, ND, DLKT iš viso rastas 41 baigmeni -eivis, $-\dot{e}$ turintis darinys ${ }^{13}$, iš jų 34 pateikti $\mathrm{LKŽ}_{\mathrm{e}}$ (7 žodžiai turi neologizmo žymą). Pasakytina, kad botanikos terminas plateive („orchidinių šeimos augalas, blandis (Platanthera)“) LKŽ $\check{\mathrm{e}}_{\mathrm{e}}$ nurodytas kaip turintis tik moteriškąą giminę, 7 žodžiai pateikti tik kaip vyriškosios giminès ${ }^{14}$ daiktavardžiai: dieneivis „,(karininko) pasiuntinys“, gireivis (neol.) „kas yra giriai atsidavęs, kas mėgsta girią, kas prižiūri girią“, kryžeivis „žr. 1 kryžiuotis“, hibridai mečeivis istor. „kalavijuotis“ ir miečeivis „kalavijuotis“, vandeneivis (neol.) ,jūrininkas“ ir žmogeivis (neol.) „paprastas, nekilmingas žmogus“. Kitais dariniais gali būti pavadinami ir vyriškosios, ir moteriškosios giminès asmenys: atbuleivis, $-\dot{e}$,

${ }^{13} \mathrm{LKŽ}_{\mathrm{e}}$ yra darinių, baigmeni -eivis, - $\dot{e}$ gavusių iš pamatinių žodžių keleivis, kareivis, moksleivis (tokie, kaip minèta, ị tyrimą neįtraukti), pvz.: draugkareivis, $-\dot{e}$, kryžkareivis, $-\dot{e}$, puskareivis, $-\dot{e}$, sq̨kareivis, $-\dot{e}$, sankareivis, $-\dot{e}$, bendrakeleivis, $-\dot{e}$, draugkeleivis, $-\dot{e}$, sqqkeleivis, $-\dot{e}$, sankeleivis, $-\dot{e}$, šventkeleivis, $-\dot{\mathrm{e}}$, sanmoksleivis, $-\dot{\mathrm{e}}$ ir kt. Pasakytina, kad iš esmès galima kalbèti apie kai kurių iš šių darinių dvejopo pamatavimo galimybę. Pavyzdžiui,

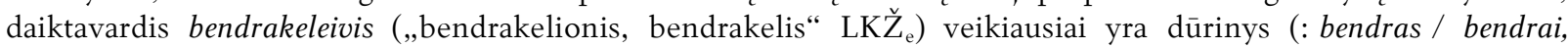
keleivis), bet galètų būti siejamas ir su žodžiais bendrai, keliauti (+ -eivis, -è), šventkeleivis (,„šventųiu vietuc lankytojas, piligrimas, maldininkas“ ${ }^{2} K \check{Z}_{\mathrm{e}}$ ) veikiausiai yra dūrinys iš šventas, keleivis, bet semantiškai ji galima sieti ir su žodžiais šventas, keliauti (+ -eivis); atkreiptinas dèmesys, kad antruoju pamatavimo atveju dariniai turi nutrūkstamą formantą, yra kompozicijos-sufiksacijos rezultatas, kur -eivis, $-\dot{e}$ atlieka priesagos funkciją.

${ }^{14} \mathrm{LKŽ}_{\mathrm{e}}$ neologizmų žymą turinčiais daiktavardžiais gireivis, žmogeivis iš esmès galima pavadinti ir moteris; žodyne prie žodžio gireivis nepateikta jokio vartosenos pavyzdžio, o žmogeivis iliustruojamas sakiniais iš Simono Daukanto raštų (Žemes ir valsčius jo mylistoms ir bajorams atidave ịsakęs tiktai žmogeiviu nespausti S. Dauk. $\mathrm{LKZ̆}_{\mathrm{e}}$ ) - tikriausiai jo tekstuose buvo vartojama tik vyriškosios giminès forma. 


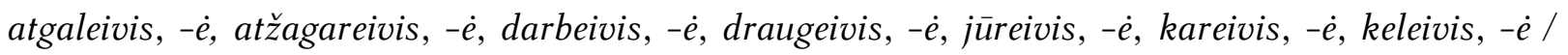

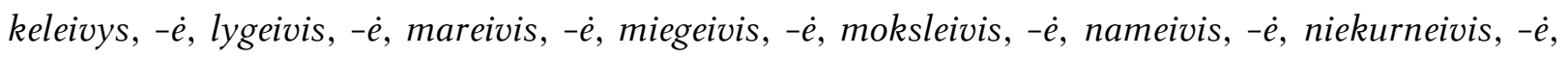
oreivis, $-\dot{e}$, pakeleivis, $-\dot{e}$, pašaleivis, $-\dot{e}$, pirmaeivis, $-\dot{e}$, pirmeivis, $-\dot{e}$, prakeleivis, $-\dot{e}$, prašaleivis, $-\dot{e}$, prekeivis, $-\dot{e}$, prošaleivis, $-\dot{e}$, rašteivis, $-\dot{e}$, upeivis, $-\dot{e}$, žygeivis, $-\dot{e}$.

LKŽPK rasti dar trys (ị LKŽ $\check{e}_{\mathrm{e}}$ neįtraukti) baigmeni -eivis turintys asmenų pavadinimai: kūleivis, lengvaeivis, važeivis, o ND - naujadarai svetimeivis, $-\dot{e}$ ir sugrižeivis, $-\dot{e}$. DLKT rasta pavyzdžiu su dar dviem ${ }^{15}$ kituose šaltiniuose neužfiksuotais baigmeni -eivis turinčiais dariniais šviesiaeivis ir tautpažangeivis.

Pasakytina, kad ne visi šie dariniai dabartinejje lietuvių kalboje vienodai dažnai vartojami - DLKT rasta daug vartosenos pavyzdžiu su daiktavardžiais ${ }^{16}$ moksleivis, $-\dot{e}$ (19 963),

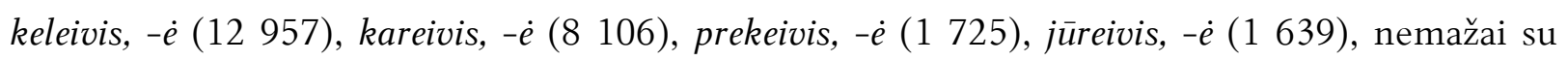
daiktavardžiais pakeleivis (383), oreivis (212), pirmeivis (118), žygeivis (56), kryžeivis (53), upeivis (48), atžagareivis (17), po vieną kitą pavyzdi su šviesiaeivis (8), pirmaeivis (3), nameivis (2), svetimeivis (2), po vieną pavyzdị su darbeivis, miegeivis, prakeleivis, prašaleivis, tautpažangeivis, žmogeivis, plateive ${ }^{17}$, tekstyne nerasta pavyzdžių su LKŽ ${ }_{\mathrm{e}}$ pateiktais daiktavardžiais dieneivis, gireivis, mečeivis, miečeivis, vandeneivis, atbuleivis, atgaleivis, draugeivis, lygeivis, mareivis, niekurneivis, pašaleivis, prošaleivis, rašteivis ir naujadarais kūleivis, lengvaeivis, sugrįžeivis, važeivis.

\section{DARINIŲ, TURINČIŲ BAIGMENI -EIVIS, - $\dot{E}$, DARYBA IR SEMANTIKA}

Ar žodis yra darinys ir koks darinys, lemia darybos opozicija. Svarstant, su kokiu žodžiu (ar su kokiais žodžiais) darybos opozicijas sudaro baigmeni -eivis, - $\dot{e}$ turintys dariniai, matyti, kad nemažos dalies darinių leksinė reikšmė rodo gana aiškią sąsają su veiksmažodžiu eiti ${ }^{18}$, t. y. dariniai semantiškai ir formaliai susiję su dviem pamatiniais žodžiais, iš kurių antrasis remiasi veiksmažodžiu eiti, ir dar turi priesagą -vis, $-\dot{e}$. Taigi, šiuo atveju reikètų kalbèti apie mišrųii -

${ }^{15}$ DLKT rasta ir ND pateikto darinio svetimeivis vartosenos pavyzdžių: ...juk neleisite svetimeiviui svetimakišeniauti Jūsu kišenèse...

${ }^{16}$ Skaičiuotos visos daiktavardžių vyriškosios ir moteriškosios giminès vienaskaitos ir daugiskaitos linksnių formos.

17 Tiesa, tekstyne rastame pavyzdyje pavartota ne moteriškosios giminès (kaip nurodyta LKŽ vyriškosios giminès forma: Čia augo švelniai kvepiančios zubražolès, pelkiniai pelèžirniai, žalieji plateiviai, pataisai, miškinès glažutès DLKT.

${ }^{18}$ Veiksmažodis eiti yra daugiareikšmis: LKŽ e pateiktos 42 veiksmažodžio reikšmės, DŽ - 23, BŽ - 27. Taigi vediniai gali remtis ne tik pagrindine (1) reikšme ,judeti iš vietos į vietą pėsčiomis, žingsniu“ $L K Z_{\mathrm{e}}$, bet ir ivvairiomis kitomis žodynų fiksuotomis reikšmėmis, pvz.: „smarkiai judèti kuria nors kryptimi“" LKŽ „,nesulaikomai slinkti, traukti, plūsti; važiuoti, plaukti (susisiekimo priemonei)“ LKŽ LKŽ ${ }_{e}$, , ,vykti“ LKŽ ${ }_{e}$, ,veikti, dirbti“ LKŽ ${ }_{\mathrm{e}}$ ir kt. 
kompozicijos-sufiksacijos - darybos būdą ir darinius su nutrūkstamu formantu. Daugumos šių darinių pirmasis dèmuo remiasi kokiu nors daiktavardžiu: miegeivis, $-\dot{e}$ „1unatikas ${ }^{19 ،,}$ t. y. kuris eina / vaikščioja per miegus (: miegas, eiti), nameivis, $-\dot{e}$ „,prekybininkas, nešiojantis prekes po namus“, t. y. kuris eina su prekèmis per namus (: namai, eiti), prekeivis, $-\dot{e}$ „keliaujantis prekiautojas, komivojažierius“, t. y. einantis / vaikščiojantis su prekèmis (: prekè, eiti), žygeivis, $-\dot{e}$ „kas mėgsta žygiuoti ar dalyvauja žygyje, turistas“, t. y. kuris eina į žygi (: žygis, eiti), gireivis „kas yra giriai atsidavęs, kas mėgsta girią, kas prižiūri girią“, t. y. kuris (vaikščiodamas, apžiūrinėdamas) rūpinasi giria (: giria, eiti), kareivis, $-\dot{e}$ „eilinis, atliekantis karo prievolę“, t. y. kuris eina ị karą, kariauti (: karas, eiti), darybiniais variantais laikytini keleivis, $-\dot{e} /$ keleivys, $-\dot{e}$ „keliautojas, keliauninkas“, t. y. kuris eina ị kelią, keliauja (: kelias, eiti), moksleivis, - $\dot{e}$ „kas mokosi mokykloje, mokinys“, t. y. kuris eina mokslus (: mokslas, eiti) ${ }^{20}$, pakeleivis, $-\dot{e}$ 1. „keleivis, keliauninkas“, 2. „keleivis, kuris keliaudamas užeina kur pailsėti, pernakvoti, atsigerti, pavalgyti“, 3. „žmogus, kuriam pakeliui su kitu žmogumi, bendrakelionis“, t. y. kuris užeina keliaudamas arba kuriam pakeliui su kuo nors kitu (: pakelè / pakeliui ${ }^{21}$, eiti), pašaleivis, $-\dot{e} 2$. „iš kitur atvykęs, nevietinis žmogus“, t. y. kuris atėjęs iš pašalès (: pašale, eiti), prašaleivis, $-\dot{e}$ (,žr. prašalaitis 3“, prašalaitis, $-\dot{e} 3$. „praeivis“), t. y. atėjęs iš prašalès, pašalès (: prašalys ${ }^{22}$, eiti), neologizmo žymą turintys darbeivis, $-\dot{e}$ „darbo vykdytojas, rangovas“, t. y. kuris eina ir prižiūri darbą (: darbas, eiti). Žmogus, kuris eina su kalaviju, vadinamas darybiniais variantais laikytinais dariniais mečeivis „kalavijuotis“ (: mečius, eiti) ir miečeivis „kalavijuotis“ (: miečius, $e i t i)^{23}$, o kuris eina su kryžiumi - kryžeivis „žr. 1 kryžiuotis“ (: kryžius, eiti).

Kai kurių darinių pirmasis dèmuo remiasi prieveiksmiu, būdvardžiu ${ }^{24}$ arba skaitvardžiu. Pavyzdžiui, LKŽPK pateiktas daiktavardis lengvaeivis sietinas su prieveiksmiu lengvai ir veiksmažodžiu eiti ${ }^{25}$. Šiokios tokios sąsajos su eiti turi asmenų pavadinimai niekurneivis, - $\dot{e}$ „,̌rr. niekurneiva“ (niekurneiva „kas niekur neina, nieko nedirba, tinginys“ (: niekur, neiti),

${ }^{19}$ Lunatikas „kas serga lunatizmu, nakviša, miegeivis“ DŽ.

${ }^{20} \mathrm{LKŽ}_{\mathrm{e}}$ veiksmažodžio eiti 2-oji reikšmè „žinių gavimas, mokymasis“ iliustruojama sakiniais su pavartotu apstabarèjusiu žodžių junginiu eiti mokslus: Kai sūnūs išaugo j metus, tèvas išleido juos mokslu eiti. Sako, vaikel, kad tu esi labai mokytas, visus mokslus išèjęs, - kreipèsi senis vèl ị mane. Primintina, kad S. Ambrazas (1993: 8-9) darini moksleivis laiko vediniu.

${ }^{21}$ Darinio pirmasis dèmuo iš esmès gali remtis ir daiktavardžiu, ir prieveiksmiu.

${ }^{22}$ Prašalys „žr. pašalys 1“, pašalys 1 . „vieta palei kraštą, pakraštys“ LKŽ

${ }^{23}$ Darinių demenys remiasi bendrinei kalbai neteiktinais slavizmais mečius („kardas, kalavijas“ LKŽ $\check{e}_{\mathrm{e}}$ ) ir miečius („,kardas, kalavijas“ $\mathrm{LKŽ}$ ). Beje, iš tokią pat reikšmę turinčių asmenu pavadinimų miečeivis ir mečeivis tik pastarasis $L K \check{Z}_{\mathrm{e}}$ turi istorizmo žymą.

${ }^{24}$ Kartais vienareikšmiškai nustatyti kalbos dali sudètinga, nes iš esmès darinys gali būti pamatuotas ir būdvardžiu, ir prieveiksmiu, todèl LKG (1965: 468-469) sykiu kalbama apie darinius iš būdvardžio arba būdvardinio prieveiksmio ir veiksmažodžio.

${ }^{25}$ LKŽPK užfiksuotas pats žodis (su nuoroda ị Simono Daukanto raštus), bet reikšmė nenurodyta ir nepateikta vartosenos pavyzdžių. 
prošaleivis, $-\dot{e}$,žr. prašaleivis“ (: prošal ${ }^{26}$, eiti), atgaleivis, $-\dot{e}$ (neol.) ,atsilikèlis, atžagareivis, reakcionierius“, t. y. kuris tarsi eina atgal (: atgal, eiti), atbuleivis, $-\dot{e}$,žr. atbuleikis 2 “ (atbuleikis „2. prk. kas vis priešinasi, vis priešingai daro, priešgyna, atžagaris“, t. y. kuris daro atbulai, tarsi eina atbulas (: atbulas / atbulai, eiti), atžagareivis, $-\dot{e}$ „kas viską daro atvirkščiai, priešingai; plg. atžagarainis, atžagaris 2“, 2. „atsilikusių pažiūrų žmogus, reakcionierius“, t. y. kuris eina atžagarias, daro atžagariai (: atžagarias / atžagariai, eiti). Darybinių variantų porą sudaro tuos pačius pamatinius žodžius pirmas ir eiti turintys jungiamuoju balsiu besiskiriantys dariniai pirmaeivis, $-\dot{e}$, ,žr. pirmeivis 1“ ir pirmeivis, $-\dot{e}$ (1. „progresyvių pažiūrų žmogus“), t. y. kuris tarsi eina pirma visų.

Su veiksmažodžiu eiti iš principo galima susieti asmenų, kurie dirba, veikia vandenyje, pavadinimus (pirmasis dėmuo remiasi vandens telkinius pavadinančiais daiktavardžiais): jūreivis, $-\dot{e}$ „,kas po jūras plaukioja...“, kitaip tariant, kuris dirba jūroje, kuris eina ị jūrą ${ }^{27}$ (: jūra, eiti), mareivis, $-\dot{e}$,jūreivis“ (: marios, eiti), upeivis, $-\dot{e}$ „upių laivybos tarnautojas ar darbininkas“ (: upè, eiti), vandeneivis, $-\dot{e}$ (neol.) ,jūrininkas“ (: vandenì, eiti).

$\mathrm{Su}$ veiksmažodžiu eiti šiokios tokios semantinès sąsajos turi naujadarai svetimeivis (,ateivis iš kosmoso (paprastai vartojama kuopinè daugiskaita svetimeiviai)“ ND) ir šviesiaeivis, veikiausiai vartojamas reikšme „einantis į šviesą“28 (Aš niekada nebuvau šviesiaeivis; Mokytojas šviesiaeivis DLKT). Šie dariniai remiasi būdvardžiu svetimas ir daiktavardžiu šviesa ${ }^{29}$.

Dalies darinių su baigmeniu -eivis, -è sąsaja su eiti išblukusi, netiesioginè, ne(be)jaučiama arba jos nèra. Tokių darinių darybos procese -eivis, $-\dot{e}$ atlieka priesagos funkciją. Pirmiausia tai pasakytina apie botanikos terminą plateive (,orchidinių šeimos augalas, blandis

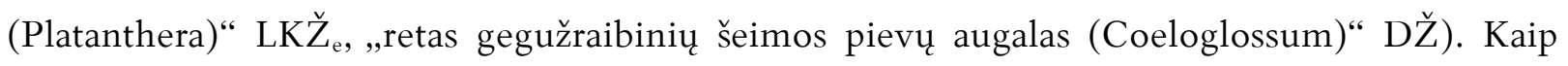
minèta (žr. Pakerys 1994: 78), šio daiktavardžio baigmuo -eive laikomas priesaga. Darinio plateive pamatiniu žodžiu eina būdvardis platus, -i. Daug įvairių ypatybių turintis augalas ${ }^{30}$ pavadintas pagal vieną iš savo požymių (apie darybos motyvacijos pasirinkimą žr. Urbutis 2009: 69-72). Plateive laikytinas vardažodinès ypatybės turètoju pavadinimų kategorijos vediniu, nes šios darybos kategorijos dariniai gali žymèti ne tik asmenị, bet ir gyvą būtybę arba daiktą pagal kurią nors būdingą ypatybę (žr. LKG 1965: 340). Dvejopai vertinamas tai pačiai darybos

${ }^{26}$ Veikiausiai darinys remiasi prieveiksmiu, nors $L K \check{Z}_{\mathrm{e}}$ pateiktas ir daiktavardis prošalis, - $\dot{e}$ „,pašalinis, svetimas žmogus“.

${ }^{27}$ Veikiausiai dèl rusų kalbos įtakos (rusiškai sakoma „išeiti ị jūrą“) buriuotojai, jūreiviai ir kt. vartojo (vartoja?) posaki eiti j jūrq (žr. https://skipperltu.wordpress.com/2015/03/06/eina-ar-plaukia/ 2019-05-25). konteksto.

${ }^{28}$ ND reikšme ir pavyzdžiai pateikti, o rastų DLKT darinių reikšmė aiškinama taip, kaip suprantama iš

${ }^{29}$ Nors pastaruoju atveju neatmestina ir pamatavimo būdvardžiu šviesus, -i galimybè, manoma, kad darinys šviesiaeivis labiau susijęs su daiktavardžiu.

${ }^{30}$ Žr. VLE (prieiga internete: http://www.vle.lt/Straipsnis/plateive-5342), plg. LRTB. 
kategorijai priklausantis asmens pavadinimas oreivis, $-\dot{e}$ (,,lakūnas, aviatorius“ LKŽ $\check{e}_{\mathrm{e}}$ ): S. Keinio (2005: 63) teigimu, sinchronijos požiūriu oreivis, $-\dot{e}$ (: oras) yra priesagos -eivis, $-\dot{e}$ vedinys, A. Pakerys (1994: 288) ši darinị pateikia prie dūrinių, kurių antrasis dèmuo yra susijęs su veiksmažodžiu eiti ${ }^{31}$. Vienu pamatiniu daiktavardžiu remiasi ir šie asmenų pavadinimai: dieneivis „(karininko) pasiuntinys“ (: diena), draugeivis, - $\dot{e}$ „draugas (?)“ (: draugas), rašteivis, $-\dot{e}$ (neol.) „raštinès vedèjas“ (: raštas), žmogeivis (neol.) „paprastas, nekilmingas žmogus“ (: žmogus). Ju darybos procese - eivis, $-\dot{e}$ taip pat atlieka priesagos vaidmenị.

LKŽ $\check{e}_{\text {e }}$ pateiktas daiktavardis prakeleivis, $-\dot{e}$ (,„̌rr. pakeleivis“ LKŽ $\left.{ }_{\mathrm{e}}\right)^{32}$ galètų būti siejamas su daiktavardžiu keleivis arba su veiksmažodžiu prakeliauti. Kadangi priešdèlio pradaiktavardžiai lietuvių kalboje paprastai žymi vietą (pvz.: pradalgé, pradanté, pralomė ir pan., žr. LKG 1965: 434; DLKG 149; plg. Paulauskienè 1983: 94; Pakerys 1994: 257), manoma, kad asmenį reiškiantis daiktavardis prakeleivis yra susijęs darybos opozicijos santykiu su veiksmažodžiu prakeliauti (,,pravažiuoti, praeiti, praplaukti“ $L K \check{Z}_{\mathrm{e}}$ ), tuomet -eivis turi priesagos funkciją. Esama ir daugiau veiksmažodinių -eivis, $-\dot{e}$ darinių. Pavyzdžiui, tokie yra LKŽPK užfiksuoti daiktavardžiai kūleivis ir važeivis. Daiktavardžio kūleivis reikšmẻ leidžia ji gretinti su priesagu -ëjas, $-a$ ir -ikas, $-\dot{e}$ vediniais, sudarytais iš veiksmažodžio $k u l t i^{33}$ :

\begin{tabular}{|c|c|c|}
\hline kūlëjas, - $a$ „kas kulia“ LKŽ & kūlikas, - $\dot{e}$ „kas kulia, kūlèjas“ & kūleivis „kūlèjas“ LKŽPK \\
\hline Kažkas smarkiai trepsi & $\mathrm{LKŽ} \check{\mathrm{e}}_{\mathrm{H}}$ & ...kulia kūleiviai kluoni... \\
\hline $\begin{array}{l}\text { priemenëje: tai grižta iš kluono } \\
\text { kūlëjai } \mathrm{LKŽ}_{\mathrm{e}}\end{array}$ & $\begin{array}{l}\text { Ruošk pietus - tuojau kūlikai } \\
\text { pareis! } \mathrm{LKŽ}_{\mathrm{e}}\end{array}$ & LKŽPK \\
\hline
\end{tabular}

Bendrašakniai dariniai kūlëjas, kūlikas ir kūleivis laikytini darybiniais sinonimais - jie sudaryti iš to paties pamatinio veiksmažodžio su skirtingais darybos formantais, turi tokią pat darybinę reikšmę, labai panašią leksinę reikšmę ir gali būti sukeisti vietomis žodžių junginiuose ar sakiniuose (plg. grižta kūlèjai - grižta kūlikai / kūleiviai, pareis kūlikai - pareis kūlëjai / kūleiviai, kulia kūleiviai - kulia kūlèjai / kūlikai) konteksto prasmei iš esmès nepasikeičiant. Daiktavardžio važeivis reikšmė papildymų kartotekoje nenurodyta ${ }^{34}$, bet iš vartosenos pavyzdžio

\footnotetext{
${ }^{31}$ Nors darinị oreivis dar šiek tiek galima sieti su veiksmažodžiu eiti (4. „nesulaikomai slinkti, traukti, plūsti || lèkti, skristi (būriu)“: Orlaivių tę - kap amaras eina! LKŽ ${ }_{\mathrm{e}}$ ), akivaizdu, kad tas ryšys blanksta.

32 Jis yra aptarto darinio pakeleivis sinonimas.

${ }^{33}$ Pasakytina, kad visi dariniai remiasi būtojo kartinio laiko forma kūlè, taigi darinys kūleivis šiuo požiūriu panašus ị veiksmažodinius priesagos - eiva vedinius (žr. LKG 1965: 330).

${ }^{34}$ Veikiausiai tai Petronėlès Orintaitės naujadaras - taip nurodoma laikraščio Dirva straipsnyje „Petronėlė Orintaitè - apybraižininke்“: „Mes tokių žodžių kaip daigynas, mandaguolis, važeivis, jauniklynas, net didžiajama žodyne neužtinkame. Tai, matyt, rašytoja pati šiuos žodžius, vadovaudamasi kalbos dvasia, sukūrè.“ (Žr. p. 6, prieiga internete: http://www.spauda.org/dirva/archive/n1972/1972-01-19-DIRVA.pdf)
} 
matyti, kad jis veikiausiai turi reikšmę „kas važiuoja“, t. y. vartojamas kaip bendrašaknių darinių važiuotojas, $-a$, važiuolis, $-\dot{e}$, važiulis, važiuoklis, $-\dot{e}$, važūnas, $-\dot{e}$ darybinis sinonimas ${ }^{35}$ :

\begin{tabular}{|c|c|c|c|}
\hline $\begin{array}{l}\text { važiuotojas, -a } \mathrm{LKŽ}_{\mathrm{e}} 1 . \\
\text { „kas važiuoja“, 2. „,kas } \\
\text { vyksta, keleivis“ } \text { LKŽ }_{\mathrm{e}} \\
\text { I juos važiuotojai ir } \\
\text { pasileido nuo smèlio } \\
\text { kalno, nesustodami } \\
\text { miestelyje } \mathrm{LKŽ}_{\mathrm{e}} \\
\text { Čia, matai, mažai } \\
\text { važiuotoju, tai neina } \\
\text { autobusas LKŽ } \\
\text { Važiuotojai, matyt, } \\
\text { skubinosi DLKT }\end{array}$ & $\begin{array}{l}\text { važiuolis, } \quad-\dot{e} \quad \text { „kas } \\
\text { važiuoja, važiuotojas, } \\
\text { keleivis“ LKŽ } \\
\text { Koks iš tavęs važiuolis } \\
\text { - traukinio bijai LKŽ }\end{array}$ & $\begin{array}{l}\text { važiuoklis, } \\
\text { „važiuotojas“ }{ }^{-} \mathrm{LKŽ}_{\mathrm{e}} \\
\text { Štai arklys, pikto } \\
\text { važiuoklio } \\
\text { nurimbuotom kojom } \\
\text { LKŽ }_{\mathrm{e}}\end{array}$ & $\begin{array}{l}\text { važeivis LKŽPK } \\
<\ldots>\text { tik šūst } \\
\text { važeivis } \quad \text { ir } \\
\text { nušvilpe } \\
\text { kubuldom ì pašali } \\
<\ldots>\text { LKŽPK }\end{array}$ \\
\hline
\end{tabular}

Šie bendrašakniai dariniai iš esmès gali pakeisti vienas kitą žodžių junginiuose ar sakiniuose (plg. čia mažai važiuotoju - čia mažai važiuoliu / važiuliu / važiuokliu / važūnu / važeiviu, koks iš tavęs važiuolis - koks iš tavęs važiuotojas / važiulis / važiuoklis / važūnas / važeivis, tik šūst važeivis - tik šūst važiuotojas / važiuolis / važiulis / važiuoklis / važūnas ir pan.), bet dabartinejje lietuvių kalboje iš šios darybinių sinonimų eilès įprasčiausias tipišką veikejju pavadinimų priesagą -tojas, -a turintis vedinys važiuotojas, - $a$, o kitų darinių vartosena itin reta ${ }^{36}$.

Naujadaro sugrįžeivis, -è („kas sugrižta iš emigracijos, reemigrantas“ ND), veikiausiai sudaryto pagal analogiją su dabartinei lietuvių kalbai įprastu asmens pavadinimu išeivis, $-\dot{e}$ (kuris išeina - išeivis, kuris sugrižta - sugrižeivis), pamatiniu žodžiu eina veiksmažodžis sugrižti, o eivis, $-\dot{e}$ atlieka priesagos funkciją. Daiktavardis sugrižeivis vartojamas kaip ịprasto (žodynuose pateikto) darinio sugrįžèlis, - $\dot{e}$ („,kas sugrįžęs“ LKŽ $\check{e}_{\mathrm{e}}$ ) sinonimas. Štai darinių sugrįžélis ir sugrižeivis, $-\dot{e}$ vartosenos pavyzdžiai:

${ }^{35} \mathrm{LKŽ}_{\mathrm{e}}$ nèra pateikta pavyzdžių su daiktavardžiais važiulis (,= važiuolis“ LKŽ važiuoja, važiuotojas“ $L K Z_{e}$ ), LKŽPK šie asmenų pavadinimai apskritai neužfiksuoti.

${ }^{36} \mathrm{DŽ} \mathrm{nefiksuotas} \mathrm{nè} \mathrm{vienas} \mathrm{iš} \mathrm{darinių,} \mathrm{į} \mathrm{BŽa} \mathrm{įtrauktas} \mathrm{tik} \mathrm{priesagos} \mathrm{-tojas,} \mathrm{-} a$ vedinys važiuotojas, $-a$, DLKT taip pat rastas 71 daiktavardžio važiuotojas, - $a$ vartosenos pavyzdys, sakinių su kitais bendrašakniais daiktavardžiais tekstyne nerasta. 


\begin{tabular}{ll|l} 
To revoliucinio elemento branduoli sudarè & $\begin{array}{l}\text { sugrižeiviams būtų sudaromos salygos } \\
\text { visavertiškai ịsitraukti } i \text { Lietuvos kalbinę } \\
\text { sugrižèliai iš Rusijos LKŽ }\end{array}$ \\
aplinka ND
\end{tabular}

Šių bendrašaknių darinių kaita vienas kitu žodžių junginiuose ar sakiniuose galima be didesnių apribojimų (plg. branduoli sudarè sugrižèeliai- branduoli sudaré sugrižeiviai, sugrižeiviams sudaromos sąlygos - sugrizżèliams sudaromos sq̨lygos ir pan.), taigi galima sakyti, kad tai gana artimos semantikos darybiniai sinonimai. Iš veiksmažodžių su -eivis, $-\dot{e}$ išvesti asmenų pavadinimai važeivis, kūleivis, sugrįžeivis laikytini veikèju ir veiksmažodinès ypatybès darybos kategorijos dariniais.

DLKT rastas baigmeni -eivis turintis daugiamorfemis (hipostazinis) darinys tautpažangeivis veikiausiai vartojamas reikšme „priklausantis Tautos pažangos partijai“ ir tiesioginès sąsajos su veiksmažodžiu eiti neturi: I euroskeptikus pretenduojantys tautininkai, tautpažangeiviai, valstiečiai, iš dalies demokratai apeliuoja $i$ patriotizma DLKT. Asmens pavadinimas tautpažangeivis veikiausiai sukurtas iš žodžių junginio ${ }^{37}$ tautos pažanga su priesagos funkciją turinčiu -eivis pagal analogiją su kitais tokį pat baigmenį turinčiais žodžiais. Šis okaziniu laikytinas darinys gali būti sukurtas tik tam vienam atvejui ir pavartotas tik tame konkrečiame publicistiniame tekste ${ }^{38}$. Visais atvejais, kai darinių (pvz., plateivè, žmogeivis, kūleivis, važeivis, sugrįžeivis ir pan.) semantikoje ne(be)jaučiamas ryšys su veiksmažodžiu eiti, baigmuo -eivis, $-\dot{e}$ atlieka priesagos vaidmenị ir galima kalbèti apie besiformuojanti darybos tipą ${ }^{39}$.

\section{DARINIŲ SU -EIVA IR -EIVIS, -E் SINONIMIŠKUMAS}

Darinių su -eiva ir -eivis, - $\dot{e}$ leksinių reikšmių analizé parodè, kad esama atvejų, kai šiuos baigmenis turintys bendrašakniai dariniai aiškinami vieni kitais, t. y. neabejotinai sudaro darybinių sinonimų poras (dažniau asmenų pavadinimai su -eiva nukreipiami i - eivis, $-\dot{e}$ turinčius darinius, bet būna ir atvirkščiai, kai darinys su -eivis, $-\dot{e}$ aiškinamas -eiva vediniu):

${ }^{37}$ S. Keinys (1999: 23) užsimena apie tai, kad lietuvių bendrinejje kalboje esama atvejų, kai suduriamas žodžių junginys ir pridedama priesaga, pvz., keturvëjininkas, $-\dot{e}$.

${ }^{38}$ DLKT rastas tik vienas žodžio tautpažangeivis vartosenos pavyzdys.

${ }^{39}$ Lietuvių kalbos darybos tipų sąrašas nėra baigtinis, pvz., S. Keinio (1999: 27) teigimu, įvardis kelioliktas, -a yra padarytas ne su kelintiniams skaitvardžiams būdinga priesaga -tas, -a, pvz., tryliktas, - $a$, devynioliktas, $-a$ ir kt., o ,iš tikrųju priklauso visai kitam, naujesniam (priesagos -intas, -a) įvardžių darybos tipui.“ 
atžagareiva ,žr. atžagareivis 2“ LKŽ

Patys atkakliausi atžagareivos čiauškëjo LKŽ

- A, tas Jurgis visada toks strampa,

atžagareiva! DLKT

niekurneiva „kas niekur neina, nieko nedirba, tinginys" LKZ̆

Senis pasidare niekurneiva, it akmuo sèdejo troboj LKŽ

kareiva 1. „žr. kareivis“ LKŽ

Šituose pokalbiuose dalyvavo vienas senas kareiva $\mathrm{LKŽ}_{\mathrm{e}}$

Tikiuosi, jis palaike mane prietaringu

bukagalviu kareiva DLKT

prekeiva „žr. prekeivis“ LKŽ

Smulkus prekeiva, klaidžiojantis po provincijos miestus LKŽ

prekeivos pardavinëjo gaiviuosius gèrimus

DLKT

upeiva ,Žr. upeivis“ LKŽ

Upeivos gabeno prekes i Rusija LKŽ atžagareivis, $-e^{40} 2$. ,atsilikusių pažiūrų žmogus, reakcionierius“ LKŽ Ar atžagareiviu virtai? $\mathrm{LKŽ}_{\mathrm{e}}$

Nejaugi jūs patikejjote šituo atžagareiviu? DLKT

niekurneivis, $-\dot{e}$, ,žr. niekurneiva“ LKZ̆

Kai tèvynès reikalai iškilo, nebebuvo nei romenu, nei helenu, nei atgaleiviu, nei pirmeiviu, nei niekurneiviu (juok.) LKŽ

kareivis, $-\dot{e}$, ,eilinis, atliekantis karo prievolę" $\mathrm{LKŽ}_{\mathrm{e}}$

Kareivis pily pastatytas $\mathrm{LKŽ}_{\mathrm{e}}$

polinkis $i$ ginklus, karine tvarka ir poezija

kareiviams kèlè didele nuostaba DLKT

prekeivis, $-\dot{e}$, ,keliaujantis prekiautojas, komivojažierius" LKŽ

Mažmeninis prekeivis $\mathrm{LKZ̆}_{\mathrm{e}}$

Mikeny prekeiviai pasiekdavo Baltijq DLKT

upeivis, $-\dot{e}$, ,upių laivybos tarnautojas ar darbininkas" LKŽ

Lietuvos upeiviai ruošèsi navigacijos sezonui $\mathrm{LKŽ}_{\mathrm{e}}$

Jos vyras upeivis DLKT

Šie bendrašakniai dariniai žodžių junginiuose ar sakiniuose iš esmès gali būti keičiami vieni kitais be didesniu apribojimų, t. y. pasižymi aukštu sinonimiškumo laipsniu, plg.: atžagareivos / atžagareiviai čiauškèjo, atžagareiviu / atžagareiva virtai, dalyvavo vienas senas kareiva / kareivis, kareivis / kareiva pily pastatytas, smulkus prekeiva / prekeivis, upeivos / upeiviai gabeno ir pan. Darinio jūreiva vartosenos pavyzdžių žodynuose nepateikta, jų nerasta ir DLKT, taigi darytina išvada, kad lietuvių kalboje šio žodžio vartosena reta. Nors teoriškai jis galètų būti pavartotas vietoj tokią pat reikšmę turinčio bendrašaknio darinio jūreivis, $-\dot{e}$ (Šaunios

\footnotetext{
${ }^{40}$ Kita reikšme (,„kas viską daro atvirkščiai, priešingai; plg. atžagarainis, atžagaris 2 “ LKŽ ${ }_{\mathrm{e}}$ ) daiktavardis atžagareivis,

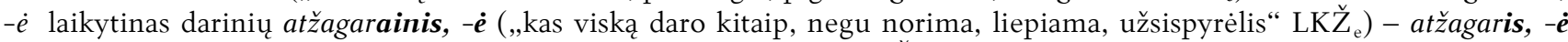

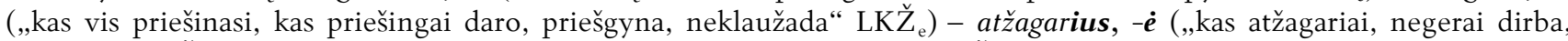
atžagaris“ $\left.L K \check{Z}_{\mathrm{e}}\right)$ - atžagarūnas, $-\dot{\boldsymbol{e}}$ (,,kas kitaip, negu visi, daro, elgiasi“ LKŽ $\left.\check{\mathrm{e}}\right)-$ atžagarvyžis, $-\dot{e}($, ,menk. kas viską atbulai dirba, atbulvyžis, užsispyrèlis“ LKŽ $_{\mathrm{e}}$ ) darybiniu sinonimu.
} 
yra mūsu šalies jūreiviu tradicijos LKŽ $_{\mathrm{e}}$; Šturmanas riktelejo, ir jūreivis metè nuo denio lyna DLKT; plg. jūreivy tradicijos, jūreiva mete lyna), bet realiai ši darybinių sinonmų pora lietuviu kalboje veikiausiai nefunkcionuoja.

IŠVADOS

1. Lietuvių žodžių darybos veikaluose skirtingais darybos tipais neretai laikomi tokią pat priesagą, bet skirtingas galūnes turintys dariniai. Darinių su baigmeniu -eivis, $-\dot{e}$ darybinè ir semantinè analizė atskleidè, kad dalis jų remiasi dviem pamatiniais žodžiais, iš kurių vienas yra veiksmažodis eiti, ir dar turi priesagą -vis, $-\dot{e}$, taigi gali būti laikomi kompozicijos-sufiksacijos rezultatu. Kai kurie dariniai sąsajos su veiksmažodžiu eiti ne(be)turi ir remiasi vienu pamatiniu žodžiu (veiksmažodžiu arba vardažodžiu). Žiūrint ị žodynuose pateiktų darinių ir naujadarų su $-e i v i s,-\dot{e}$ visumą, t. y. atsiribojus nuo darinių individualių darybinių reikšmių, $-e i v i s,-\dot{e}$ darinius sugretinus su priesagos -eiva ir kitu priesagu bendrašakniais sinonimiškais vediniais manytina, kad sinchroniškai tam tikrais atvejais -eivis, $-\dot{e}$ galima laikyti priesaga.

2. Didesnè darinių su -eivis, $-\dot{e}$ dalis (92 proc. visų darinių) vartojami kaip vardažodinès ypatybės turètoju darybos kategorijos dariniai, kai kurie (8 proc.) kaip veikejų ir veiksmažodinès ypatybės turètojų darybos kategorijos dariniai. Taigi, žodžių darybos veikaluose šiose darybos kategorijose greta pateikto -eiva darybos tipo būtų tikslinga nurodyti ir besiformuojanti -eivis, $-\dot{e}$ darybos tipą.

3. Žodžių daryboje veikia analogija, naujų darinių nuolat pasidaroma pagal esamus darybos modelius. Kaip rodo ND, DLKT medžiaga, lietuvių kalboje atsiranda ir, tikètina, atsiras daugiau naujadaru su -eivis, $-\dot{e}$, kurie papildo ir papildys esamų asmenų pavadinimų gretą.

\section{ŠALTINIAI}

BŽ - Bendrinès lietuviu kalbos žodynas (rengiamas). Vyr. red. D. Liutkevičienè, Vilnius: Lietuvių kalbos institutas. Prieiga internete: http://bkz.lki.lt.

BŽa - Bendrinès lietuvių kalbos žodyno antraštynas. Prieiga internete:

http://bkz.1ki.1t/antrastynas/?pg=c (žiūrèta 2019 m. birželio-rugpjūčio mèn.).

DLKT - Dabartines lietuviu kalbos tekstynas. Prieiga internete:

http://tekstynas.vdu.lt/tekstynas/ (žiūrèta 2019 m. birželio-rugpjūčio mẻn.).

DŽ - Dabartinès lietuvių kalbos žodynas. Vyr. red. S. Keinys. Vilnius: Lietuvių kalbos institutas, 2012. Prieiga internete: http://1kiis.lki.lt/dabartinis. 
LKŽ $\check{\mathrm{e}}_{\mathrm{e}}$ - Lietuvių kalbos žodynas, t. 1-20, 1941-2002 (elektroninis variantas), vyr. red. G. Naktinienè, Vilnius: Lietuvių kalbos institutas, 2005. Prieiga internete: www.lkz.lt.

LKŽPK - Skaitmeniné „Lietuvių kalbos žodyno“ papildymu kartoteka. Vilnius: Lietuvių kalbos institutas, 2015. Prieiga internete: http://1kiis.1ki.lt/antra-kartoteka.

TB - Lietuvos Respublikos terminy bankas. Prieiga internete: http://terminai.vlkk.lt/pls/tb/tb.search (žiūrèta 2019 m. birželio-rugpjūčio mèn.).

ND - Miliūnaitė R., Aleksaitė A. Lietuvių kalbos naujažodžių duomenynas [Tęstinis internetinis žinynas nuo 2011 m.]. Sudarytoja Rita Miliūnaitė. Vilnius: Lietuvių kalbos institutas. Prieiga internete: http://naujazodziai.lki.lt (Žiūrèta 2019 m. birželio-rugpjūčio mèn.). https://doi.org/10.35321/neol.

VLE - Visuotiné lietuviu enciklopedija (elektroninis variantas), Vilnius: Mokslo ir enciklopediju leidybos centras. Prieiga internete: http://www.vle.lt/.

\section{LITERATŪRA}

Ambrazas S. 1993: Daiktavardžiu darybos raida: lietuviu kalbos veiksmažodiniai vediniai, Vilnius: Lietuvių kalbos institutas.

Ambrazas S. 2002: Daiktavardžiu darybos raida 2, Vilnius: Mokslo ir enciklopedijų leidybos institutas.

DLKG 2005 - Dabartinès lietuviu kalbos gramatika. Red. V. Ambrazas, Vilnius: Mokslo ir enciklopedijų leidybos institutas.

Gudzinevičiūtė O. L. 2008: Lietuviu kalbos substantiva communia. Daktaro disertacija, Vilniaus universitetas.

Keinys S. 1999: Bendrinès lietuviu kalbos žodžiu daryba, Šiauliai: Šiaulių universiteto leidykla.

Keinys S. 2005: Dabartine lietuvių terminologija, Vilnius: Lietuvių kalbos institutas.

Kniūkšta P. 1998: Darybinè ir darybos reikšmè. - Kalbos kultūra 71, 29-30.

Gaivenis K., Keinys S. 1990: Kalbotyros terminu žodynas, Kaunas: Šviesa.

LKG 1965: Lietuvių kalbos gramatika 1, Vilnius: Mintis.

LKG 1971: Lietuvių kalbos gramatika 2, Vilnius: Mintis.

Pakerys A. 1994: Akcentologija 1, Kaunas: Šviesa.

Pakerys A. 2002: Akcentologija 2, Vilnius: Mokslo ir enciklopediju leidybos institutas.

Paulauskienè A. 1983: Lietuvių kalbos morfologijos apybraiža, Kaunas: Šviesa.

Paulauskienè A. 1994: Lietuviu kalbos morfologija. Paskaitos lituanistams, Vilnius: Mokslo ir enciklopedijų leidykla. 
Skardžius P. 1996: Rinktiniai raštai 1: Lietuvių kalbos žodžiu daryba, Vilnius: Mokslo ir enciklopedijų leidykla.

Smetona A. 2005: Pagrindinių darybos būdų skyrimo klausimu. - Acta Linguistica Lithuanica $52,83-85$.

Urbutis V. 2009: Žodžių darybos teorija, Vilnius: Mokslo ir enciklopedijų leidybos institutas.

Vaskelienè J. 2013: Darybinių sinonimų, darybinių variantų ir paronimų panašumai bei skirtumai. - Žmogus ir žodis: Didaktiné lingvistika 5(1), 206-214.

Gauta 20190820

Priimta 20191218

\section{ON THE DERIVATIVES WITH THE ENDING -EIVIS, $-\dot{E}$}

\section{Summary}

In the Lithuanian language, there are four main types of word derivation: suffixation, prefixation, paradigmation, and composition. There are cases when two types of derivation occur at the same time: prefixation and suffixation, composition and suffixation, therefore, there is a mixed type of derivation. The nouns are derived using all types of word derivation, especially by means of suffixation. According to derivational meaning, the derivatives are classified into derivational categories. There are 13 categories of noun derivation, which have a certain number of types. Often there are different types of derivation in the same derivational category, which are composed (formally) with the same suffix, but different endings, e.g. -iezis, $-\dot{e}$ and $-\dot{e} z ̌ i u s,-\dot{e},-l y s,-\dot{e}$ and $-l a,-\dot{e} l i s,-\dot{e}$ and $-\dot{e} l a$. There are derivatives naming persons, which have similar endings: -eiva and -eivis, $-\dot{e}$. The derivatives with the suffix -eiva are mentioned in the writings on word formation, and the derivatives with -eivis, $-\dot{e}$ are scarcely mentioned. The object of the research is the nouns ending in eivis, $-\dot{e}$. The aim of the paper is to discuss the semantic and derivational particularities of derivatives ending in -eivis, $-\dot{e}$. To achieve the aim the following objectives have been set up: from the scientific literature to collect and present the data about the suffix / ending - eiva and -eivis, - $\dot{e}$; from Dictionary of the Lithuanian Language, Dictionary of Modern Lithuanian, headwords of Dictionary of Standard Lithuanian, Digital Supplement Catalogue of the Lithuanian Language Dictionary to collect the names of persons with the ending -eivis, $-\dot{e}$, to supplement them with the data from Database of 
Lithuanian Neologisms and the Corpus of the Contemporary Lithuanian Language, to discuss the semantics and derivation of derivatives ending in $-e i v i s,-\dot{e}$.

In total 41 derivatives with the ending -eivis, $-\dot{e}$ have been found in the mentioned resources (34 of them have been fixed in Dictionary of the Lithuanian Language). After the analysis of the formation and semantics of the derivatives ending in -eivis, $-\dot{e}$, the following conclusions have been drawn:

1. One part of the derivatives with the ending $-e i v i s,-\dot{e}$ are based on two underlying words, one of which is a verb eiti with a suffix $-v i s,-\dot{e}$, therefore, they are considered to be the result of composition-suffixation. Some of the derivatives with the ending -eivis, $-\dot{e}$ do not have the coherence with a verb eiti and are based on one underlying word. Considering the totality of derivatives and neologisms with the ending -eivis, $-\dot{e}$ presented in the dictionaries, i.e. distancing from the individual derivational meanings of the derivatives, and comparing the derivatives ending in -eivis, $-\dot{e}$ with cognate synonymic derivatives of the suffix -eiva as well as other suffixes, it is assumed that in some cases -eivis, $-\dot{e}$ has to be considered as a suffix.

2. The bigger part of the derivatives ending in -eivis, $-\dot{e}$ (92 per cent) are used as the derivatives of the derivational category of the possessors of nominal particularities, some of them ( 8 per cent) are used as the derivatives of the derivational category of the actors and the possessors of verbal particularities. Therefore, in the writings on word derivation, in these derivational categories, alongside the presented -eiva derivational type it is purposeful to indicate the emerging -eivis, $-\dot{e}$ derivational type.

3. There is an analogy in word formation, and new derivations are constantly being created according to existing patterns of derivation. According to Database of Lithuanian Neologisms and the Corpus of the Contemporary Lithuanian Language material, in the Lithuanian language occur and likely will occur more neologisms with the ending -eivis, -e, which supplement the rank of existing personal names.

KEYWORDS: derivational method; derivational category; derivational type; ending; suffix; synonymity.

JOLANTA VASKELIENE

Šiaulių universitetas

P. Višinskio g. 38, LT-76352 Šiauliai jolanta.vaskeliene@su.lt 